\title{
洛東江河口域における堆積物・沈降物の性状に関する研究
}

\section{A study on the characteristic of deposited and settling matter in the Nakdong River Estuary}

\author{
金キョンヘ ${ }^{1}$ ・池原貴一 ${ }^{2}$. 李 寅鉄 $^{3}$. 日比野忠史 ${ }^{4}$ \\ Kyung-hoi KIM, Kiichi IKEHARA, In-cheol LEE and Tadashi HIBINO
}

\begin{abstract}
In order to investigate transportation of organic mud in the Nakdong River Estuary, deposited and settling organic matter sampled in the Nakdong River Estuary was compared with data in the Hiroshima Bay. And the function of tidal flat was evaluated from continuous observation of ground water level, groundwater temperature, and salinity. After considering these results, it is found that property of organic mud, which is mainly supplied from Nakdong River, is similar to the property of organic mud in the constructed tidal flat in Hiroshima bay (Onomichi Itosaki constructed tidal flat). Additionally the river-mouth bar is formed by sand due to its high permeability.
\end{abstract}

\section{1.はじめに}

釜山は韓国第一の港湾都市であり，韓国の四大河川の 1つである洛東江は釜山における水の供給源である。洛 東江の流域面積は $23,560 \mathrm{~km}^{2}$, 計画高水量は $18,300 \mathrm{~m}^{3} / \mathrm{s}$ で ある. 洛東江河口には, 豊かな自然干潟が存在しており, 生物生息場として保存されることが望まれている。しか し，洛東江河口域ではロクサン工団の造成を初めに，河 口ダムや下水処理場, 新港の建設により, 海岸線の大規 模な変化が生じた. 特に1987年の河口ダムの建設後, 淡 水流出が水門によって調節され, 流れ場や海底地形の変 動, 砂州の消滅・生成の反復, 航路の埋没や狭窄化など が生じ, 海難事故や低地帯の浸水被害が増加している. そのため, 航路維持や通水路確保のための継続的な浚渫 が行われている (Kim et al., 2001). また, 工業廃水や生 活廃水が沿岸域に流入することで污染物質が海底に蓄積し ており，流れの構造が変化することで断続的に富栄養化や 貧酸素水塊が発生している状態である (Lee et al., 2005).

本研究は, 洛東江周辺の開発に伴う水環境保全のあり 方について検討し, 洛東江河口での干潟環境を創造する ための様々な知見を得ることを目的としている. 洛東江 河口に沈降・堆積する有機泥の性状とこれまで広島湾奥 〜太田川デルタ干潟で調査した有機泥の性状に関する 種々のデータと比較することによって, 洛東江河口にお ける有機泥の輸送について検討する. 具体的には洛東江 河口干潟において沈降・堆積する有機泥を採取し, 含水 比, 有機物含有量等を分析することによって, 沿岸に沈

\begin{tabular}{|c|c|c|}
\hline \multicolumn{2}{|l|}{1 学生会員 } & $\begin{array}{l}\text { 広島大学大学院工学研究科社会環境シス } \\
\text { テム専攻 }\end{array}$ \\
\hline 2 学生会員 & & $\begin{array}{l}\text { 広島大学大学院工学研究科社会環境シス } \\
\text { テム専攻 }\end{array}$ \\
\hline 3 非会員 & 博 (工) & 韓国釡慶大学校副教授海洋工学科 \\
\hline 4 正会員 & 博 (工) & $\begin{array}{l}\text { 広島大学准教授大学院工学研究科社会環 } \\
\text { 境システム専攻 }\end{array}$ \\
\hline
\end{tabular}

降・堆積した有機泥の性状把握を行った. さらに, 現地 砂洲において干潟地盤内の塩分・水温および水位の連続 測定を行い干潟機能について検討した。本論文では河口 周辺に堆積する有機泥に含まれる有機物量とその性状に 着目し, 干潟地盤の浸透性と有機物の分解状況から河口 に形成された砂洲の水環境への影響を考慮した。

\section{2. 洛東江河口での水理特性と環境調査の概要}

図-1に洛東江河口の地形および観測地点を示した。河 川水の流出があるのは写真東側の河川であり, 西側の 2 つの河川からの淡水流出はない. 1980 年の砂洲面積が $2.6 \mathrm{~km}^{2}$ であったが，2000年には $3.3 \mathrm{~km}^{2}$ になっており河口 域は堆積傾向にある (Lee et al., 2001). 河口沖には4つ の砂洲（西側からジヌ島 $0.92 \mathrm{~km}^{2}$, シンザ島 $0.66 \mathrm{~km}^{2}$, ジ ヤンザ島 $0.59 \mathrm{~km}^{2}$, ベッハプッ゙ン $\left.0.37 \mathrm{~km}^{2}\right)$ が存在してお

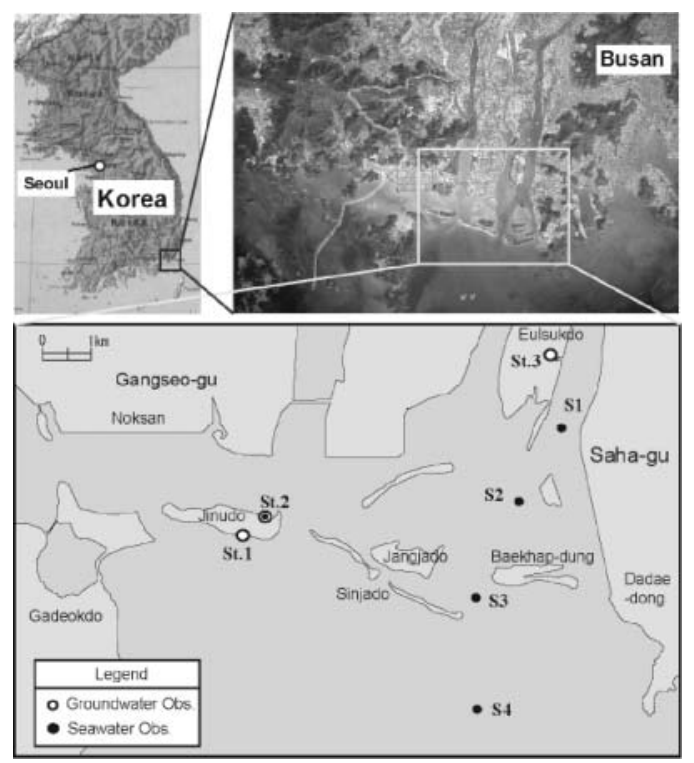

図-1 観測地点と地形概要 


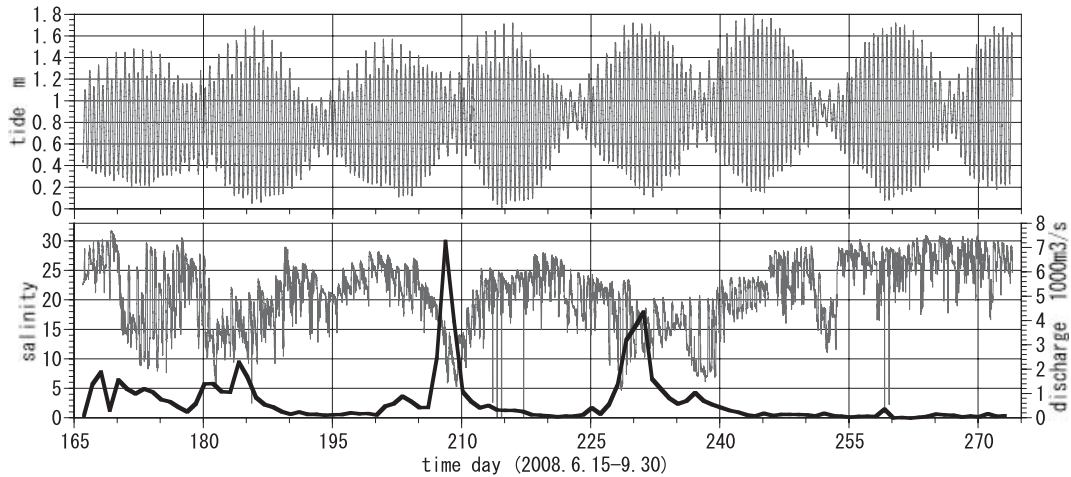

(a) 潮位と塩分, 河口ダムからの放水量

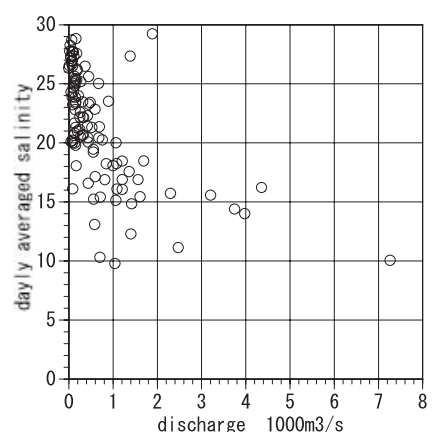

(b) 放水量と日平均の塩分の関係

図-2 潮流と河川流出に伴う砂洲北側（St.2）での塩分状態（2008年6月15日～9月30日）

り，砂洲にはあし等の塩性植物が繁茂している．採泥お よび水質の連続調查地点は西側砂洲（ジヌ島）の南側 (St.1) と北側（St.2）および水門下流河岸（St.3）に設け た. 塩分プロファイル調查はS $1 \sim \mathrm{S} 4$ において行った。 調查期間は2008年6月 15 日〜9月 30 日である.

\section{（1）洛東江河口での水理特性}

海域への河川水の放流は水門によって制御されてお り, 平水時には $200 \sim 500 \mathrm{~m}^{3} / \mathrm{s}$ 程度流量が放出されている. 河口域（St.3）での塩分は潮汐の影響を受けているが, 満潮時の塩分は 12 程度で淡水の影響が強い河口である. 河口沖の砂洲は外海側の流れと河川水の流出による流れ が干渉し合うことによって形成されており，砂洲の南北 では海底泥の性質が大きく異なっている，砂洲の北側で

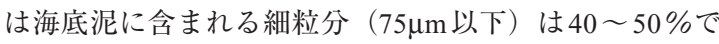
あるのに対し，南側では細粒分は含まれていない。

図-2に2008年6月 15 日〜9月30日に砂洲北側のSt.2で 測定された（a）潮位と塩分, 河口ダムからの放水量, (b) 放水量と日平均の塩分の関係を示した。潮汐変動は 大潮期に約 $1.6 \mathrm{~m}$ ，小潮期に $0.2 \sim 0.7 \mathrm{~m}$ であり，広島湾の $1 / 2$ 以下である. 河口から $6 \mathrm{~km}$ 以上離れた St.2での非出水 時の塩分は 30 程度で太田川河口に比較して低い值を示し ており，砂洲北側に平水時にも淡水が滞留していること が推定できる. 平水時の河川流出量は広島太田川の 10 倍 程度の流出がある. 出水によって指数関数的に塩分は低 下しており, St.2においても数 $1000 \mathrm{~m}^{3} / \mathrm{s}$ の出水に対して 10 程度まで低下している。ちなみに太田川で $6000 \mathrm{~m}^{3} / \mathrm{s}$ の ピーク流量に対して河口から $4 \mathrm{~km}$ の海域では $25 \mathrm{psu}$ 程度 までの低下でしかなく, 洛東江河口での河川水の滞留時 間が長いことが理解できる．図-3に 24 時間平均（17日 11 時〜 18 日 10 時） $900 \mathrm{~m}^{3} / \mathrm{s}$ の出水があった下げ潮時の河口 測線（S1～S4）に沿う塩分プロファイルを示した．洛東 江河口では砂洲の間にもシルが形成され河川水が滞留す る構造がつくられている.この地形のための河口での塩 分は6以下まで低下している。

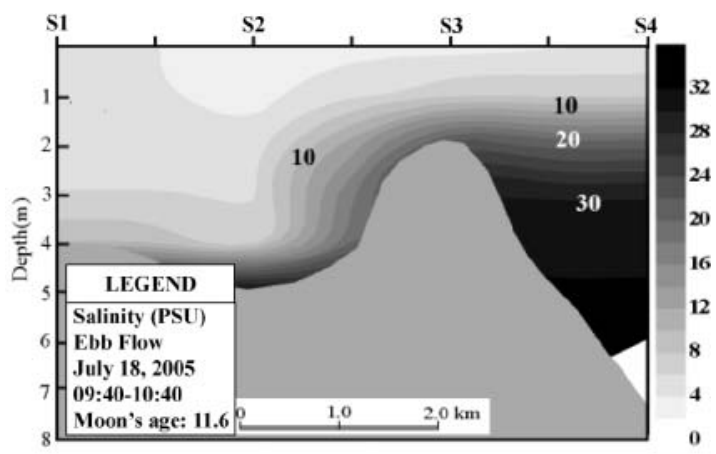

図-3＼cjkstart洛東江河口での塩分プロファイル（2005.7.18）

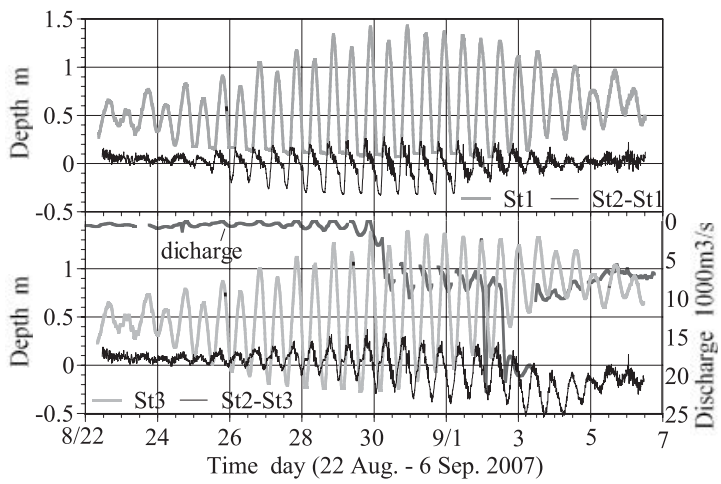

図-4 洛東江河口での水位関係

図-4にジヌ島北側のSt.2での水位を基準とした河口周 辺の水位関係を示した。測定期間は2007年 8 月 22 日〜9 月7日であり，上段にはSt.1，下段にはSt.3での水位が示 されている.干潟時にSt.2の水位が低く現れるのはSt.1 の水圧計の設置水深が高く大潮干潮時に干出するためで ある.St.2における潮汐の振幅はSt.1 と St.3に比較して大 きく，この現象が大潮期に向かって顕著に現れている. 上げ潮初期にはSt.2ではSt.1 と St.3 よりも水位が高くなっ ていくが，満潮に近づくにつれ，先ずSt.1で高く，平均 潮位付近になるとSt.3で水位が高くなっている。これは 


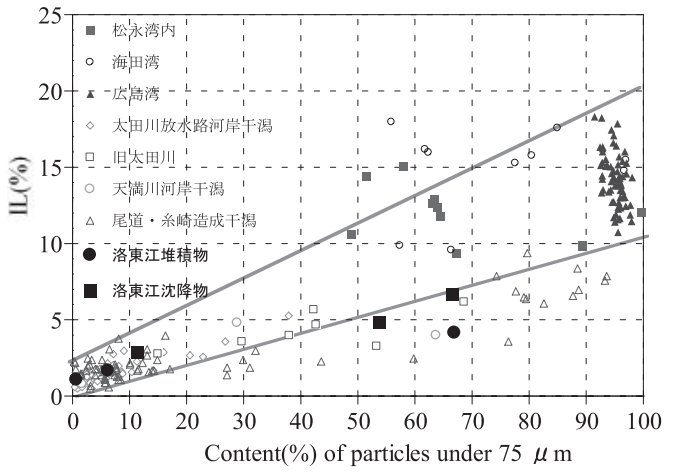

図-5 細粒分含有量と有機物量の関係

干潮時に西側海域の高い水位が残存するが, 平均潮位を 越える頃に南側からの上げ潮流が卓越してくるためであ ると考えられる．また， 8 月 30 日からの $5000 \mathrm{~m}^{3} / \mathrm{s}$ を超え る出水に伴って, 河口（St.3）での水位上昇が顕著に現 れており，流出水が河口域に溜まることによって河口の 水位を上昇させていることがわかる.

\section{（2）沿岸域に沈降・堆積する有機泥の性状と干潟機能 調査の概要}

砂洲干潟地盤内の流れとそこに沈降・堆積する䀣濁態 物質の特性について検討する. 堆積泥と沈降泥の採取, 採取泥の分析, および海中〜干潟堆積泥内における水位, 塩分, 水温の連続測定を行なった.

\section{a) 沈降泥, 堆積泥の採泥調查}

堆積泥の採取およびセディメントトラップによる沈降 物捕集調査はSt.1〜St.3で行った. セデイメントトラッ プの設置期間は2008年 8 月 20 日〜9月 2 日までの 2 週間で あり，地表から約 $20 \mathrm{~cm}$ の位置に上端が位置するように 設置した. 設置時に現地表層（0〜 $10 \mathrm{~cm}$ 深）の堆積物を 採取した。採取された堆積物・沈降物は， $75 \mu \mathrm{m}$ でふる い分けを行い, 分別された試料は各々湿重量, 含水比, 強熱減量 (IL), 元素量 $(\mathrm{C}, \mathrm{N})$, 粒度分布が測定された。 細粒分の粒度分布測定にはレーザー回析式粒度分布計 （SHIMADZU, SALD-2000）を用いた。

\section{b) 河口干潟での浸透調查の概要}

採泥を行った同じ 3 地点において, 深さ $1 \mathrm{~m}$ の観測井を 設置し，塩分・水温・水深を連続測定した. 観測井の-60 〜-80cmにストレーナーを設け，-70 cm にセンサーを設置 した. St.1とSt.2では河口に形成された砂洲の水際，St.3 では河岸に設置することで海水または河川水と地下水の 水温・塩分・水位の変動が測定された。

\section{3. 洛東江河口における沈降泥, 堆積泥の特性}

図-5には 瀬戸内海西海域に存在する干潟および海底で 採取された有機泥と洛東江河口で採取された有機泥の細 粒分含有量とILの関係が示されている，広島湾海底泥は

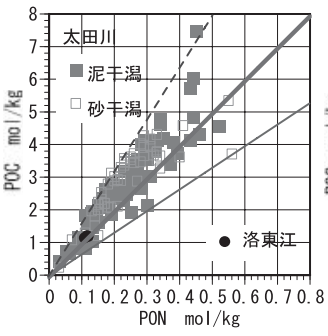

(a-1)沈降泥

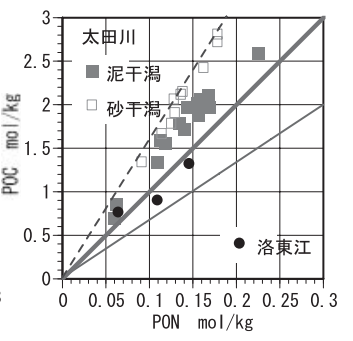

(a-2)堆積泥 (a) $\mathrm{PON} \sim \mathrm{POC}$ 関係

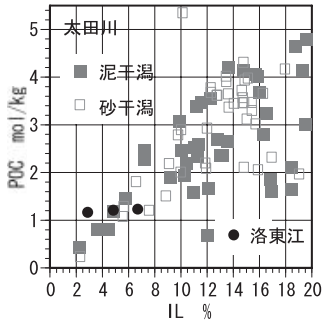

(b-1)沈降泥

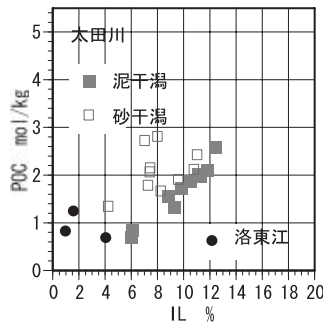

(b-2)堆積泥
(b)IL $\sim \mathrm{POC}$ 関係

図-6 洛東江河口と広島湾での沈降泥堆積泥の観測結果

$90 \%$ 以上が $75 \mu \mathrm{m}$ 以下の細粒分で構成されており，有機 物を 10 ～20\%程度含有している。

閉鎖性の強い海田湾, 松永湾には広島湾内の堆積泥よ りも含水比（水分保持能力）の高い有機泥が存在してい る. 一方, 尾道・糸崎港付近の造成干潟では細粒分の含 有率割合に対する有機物含有量が低く, 干潟地盤に含ま れる有機物量は広島湾内の堆積泥に比較して少ない。干 潟のように有機物の分解率が高い場では細粒分に付着す る有機物も分解されやすく, シルト以下の細粒分に付着 する有機物量は生物環境に依存するために細粒分の含有 量に対する含水比（水分保持量）が少なくなっている. 分解が進んだ有機物にはPON (有機懸濁態窒素) に比較 してPOC (有機懸濁態炭素) が多く含まれている. 堆積 域の環境によって有機泥に付着する有機物の分解状態が 異なっており, 有機泥の性状を分析することで有機泥の 履歴を推定できる可能性がある. 洛東江河口で採取され た有機泥では, 堆積泥, 沈降泥とも有機物含有量はアサ リが優先して棲息する尾道・糸崎干潟に堆積する有機泥 と同様の傾向を有している.

\section{（1）太田川デルタ干潟砂泥との比較}

図-6には洛東江河口と太田川デルタに形成された河岸 干潟で採取された沈降泥と堆積泥の有機物組成（(a) $\mathrm{PON} \sim \mathrm{POC}$ 関係，（b） IL 〜 POC関係）が比較されてい る.太田川デルタ干潟での值は2003〜2008年に河口か ら $8 \mathrm{~km}$ の範囲で採取された有機泥の測定值である.太実 線は易分解性の有機物が分解した後の比 $\mathrm{C} / \mathrm{N}=10$ （西村 ら，2008）である，細実線はレッドフィールド比の 


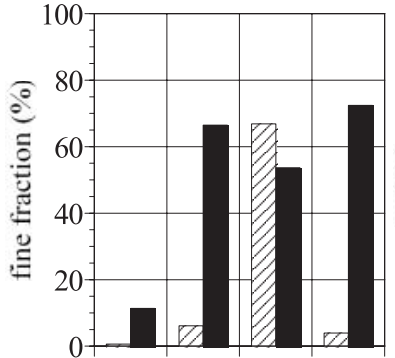

St. 1 St. 2 St. 3放水路

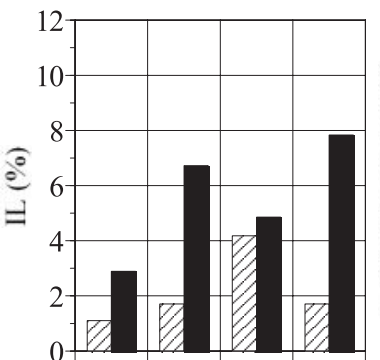

St. 1 St. 2 St. 3放水路

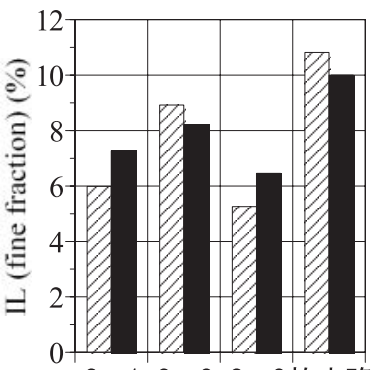

St. 1 St. 2 St. 3放水路

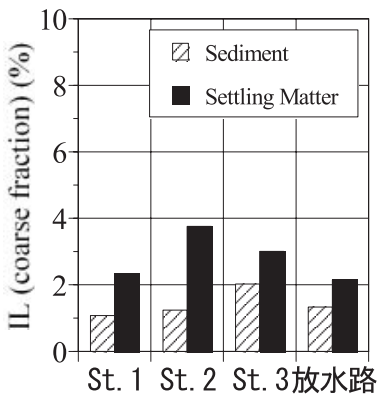

(d) 粗粒分に含まれる有機物量

(a) 細粒分割合

(b) 有機物含有量

(c) 細粒分に含まれる有機物量

図-7 洛東江河口と太田川放水路砂干潟における, 堆積泥と沈降泥の性状比較

$\mathrm{C} / \mathrm{N}=6.625$, 破線は $\mathrm{C} / \mathrm{N}=16$ を示している．太田川デル 夕干潟に沈降・堆積する有機泥の $\mathrm{C} / \mathrm{N}$ 比は $10 \sim 16$ の間に あり，分解の進んだ有機物あるいは一次生産起源でない 有機物を含んだ有機泥が多くを占めているのに対し，洛 東江河口では $\mathrm{C} / \mathrm{N}$ 比が 10 程度の比較的新鮮な有機物を含 んだ有機泥である．洛東江河口で沈降する有機泥に含有 する有機物量は少ないが，有機物量に対する POC量は砂 洲（St.1 とSt.2）で大きい傾向にある.

太田川デルタ干潟での堆積泥の IL〜 POC 関係によって 泥干潟と砂干潟に分類することができており，この関係 を用いればILに対してPOCが大きいSt.1 と St.2 は砂干潟， St.3は泥干潟に分類される.

\section{（2）洛東江河口周辺で輸送される有機泥の粒度特性}

図-7には (a) 堆積物・沈降物に含まれる細粒分含有量, （b）試料全体のIL，（c）細粒分中に含まれるIL，（d）粗 粒分中に含まれるILが示されている，河口周辺に沈降 • 堆積する有機泥には砂洲の影響が強く現れており，細粒 分の含有量が大きく異なっている．細粒分中と粗粒分中 に含まれる有機物割合（図-7 (c) と（d)）を比較すると, 細粒分中には 5〜9\%程度，粗粒分中には $1 \sim 4 \%$ 程度の 有機物が含まれている。 C/N 比，IL，粒径から砂洲を構 成する材料および砂洲の南側で移流している有機泥には 一次生産された有機物の付着が多いことが考えられる.

細粒分（100\%）のIL值を図-5にプロットすると広島 湾海底泥（10～20\%）の $1 / 2$ 程度の有機物含有量であり, 開放的な海岸に形成される砂干潟の堆積泥の細粒分に含 有される有機物量と同程度であること，太田川デル夕の 砂干潟の細粒分には広島湾海底泥と同程度の有機物が含 まれていることがわかる。これらの特性は移流されてい る有機泥に扔いても，難分解性の有機物は付着した細粒 分から脱着することが困難であることを示している.

(3) SS フラックス及び細粒分フラックス

図-8にはセディメントトラップに捕捉された沈降物 flux と細粒分のみの flux を示している。細粒分は砂洲北 側（St.2）では約 $4 \mathrm{~g} / \mathrm{m}^{2} /$ 時の fluxであり，広島湾での約

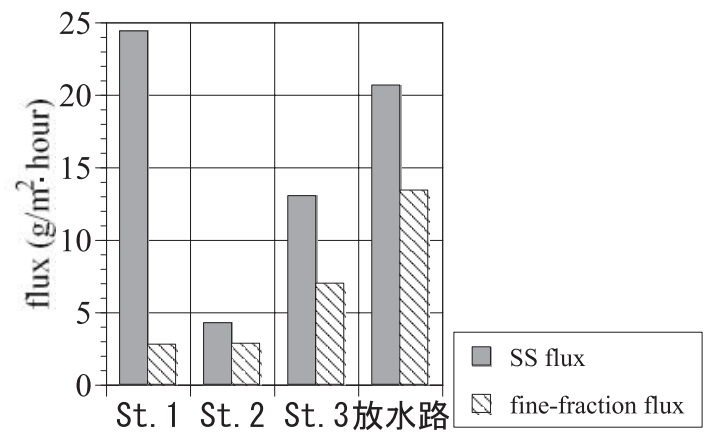

図-8 SS flux と fine fraction flux の比較

$20 \mathrm{~g} / \mathrm{m}^{2} /$ 時と比較して $1 / 5$ 程度の沈降量であり, 広島湾に 比較して細粒分の供給が少ないことがわかる．St.1では 太田川デルタでの沈降泥に比較して粗粒分の割合が極め て多いことから粗粒分の輸送量が大きい（流れが強い） ことがわかる．さらに，砂洲の北側海底には $40 \sim 50 \%$ の細粒分が含まれ，南側海底では細粒分が含まれていな いこと，沈降泥のPOCとPONの残在量が同量である (図-6（a)）こと，河口〜砂洲間に堆積した細粒分が再浮 遊し易い状態にあることを考虑すれば，有機物の消費が 効率的に行われていることが推定できる．河道内（St.3） での細粒分 fluxが大きくSt.3に堆積する有機泥のIL值が 最も大きいことから輸送されている懸濁物質には洛東江 起源の細粒分（有機泥）が多く含まれていることが推定 される。

\section{（4）細粒分の挙動}

砂洲南側の St.1 は外海の影響を強く受ける場所であり, 堆積物・沈降物ともに細粒分含有量が少ない (20\%以下) のに対し, 河道内のSt.3では, 堆積物・沈降物ともに $50 \%$ 以上の細粒分が含まれている．砂洲北側の St.2の堆 積物に含まれる細粒分は $5 \%$ 程度であるが，沈降物には 細粒分が 70\%程度含まれている．St.2では沈降泥に含ま れる有機物が最も多いが，堆積泥に含まれる有機物量が St.1 と同程度である（図-5).St.2での堆積泥，沈降泥の 細粒分と ILの特性は放水路に形成される砂干潟の特性と 


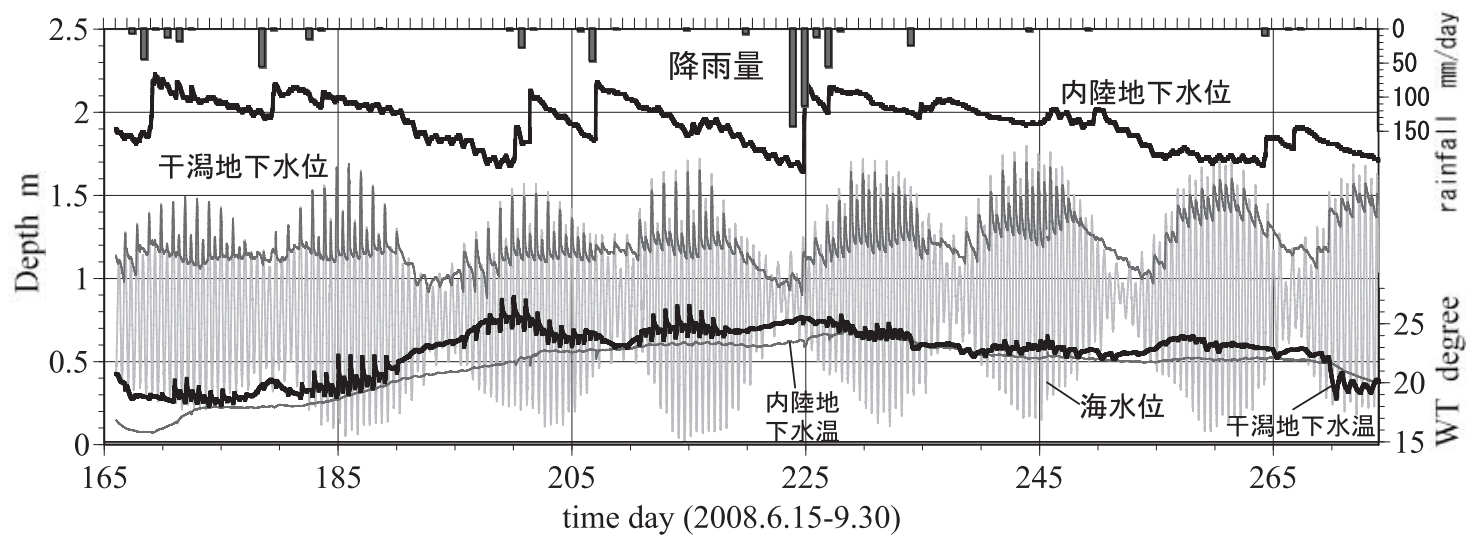

図-9 内陸〜干潟での地下水位の関係

類似しており，放水路干潟と同様に有機物を多く含んだ 細粒分を処理できる機構が河口砂州に形成されていると 考えられる。

\section{（5）砂洲干潟（ジヌ島）地盤の透水特性}

ジヌ島のSt.1〜 St.2に至る内陸部には凹部があり, 雨 水や大潮時に浸入した海水が凹部に保持されている。こ のため内陸部には湿地が形成され, 湿地には莘が繁茂し ている. 図-9にはSt.2で観測された内陸〜干潟での地下 水位, 海水位および日降雨量が示されている.内陸部の 地盤は砂質であり, 観測井設置時には地下水の流れが確 認されている.

内陸部の地下水位は降雨によって上昇し, 平常時に地 下位が低下していくことから干潟方向への活発な地下浸 透が起こっている.このことを裏付けるもう一つの現象 として, 干潟地下水と内陸地下水の水温変動に着目した. すなわち, 降雨がない場合, 干潟地下水温は潮汐の影響 を受けて変化しているが, 降雨を経験した後には内陸地 下水と干潟地下水の水温が近づいており, 内陸地下水が 干潟地下水と混合していることが推測される。このよう な地下水の交換が発生することで, 干潟の地下水面は干 潮時にも高い位置に維持されていると考えられる.

一方，太田川放水路においては活発な地下浸透によっ て高い地下水位が維持されるだけでなく, 細粒分の堆積 が抑制され砂干潟が形成される機構が観測されており (日比野ら，2008），ジヌ島周辺に形成された砂干潟にお いても，これと同様な水循環機構を有していることが考 えられる.

\section{4. おわりに}

（1）洛東江河口域において, 潮汐変動は広島湾の $1 / 2$ 程 度, 河川流出量は太田川の 10 倍程度, 塩分は太田川河 口より低く, 出水の増加に伴い指数関数的に低下して いる。これは河口域に形成されるシルが原因であり，
これによって河川水の滞留時間が長くなっている.

（2）洛東江河口で採取された有機泥は非常に強い刺激臭 であるにも関わらず, 堆積泥, 沈降泥とも有機物含有 量は有用二枚貝の棲息する尾道・糸崎干潟に堆積する 有機泥と同様の傾向を有している.

（3）河口〜砂洲間に堆積した細粒分が再浮遊し易い状態 にあることが推定できる，また， C/N比， IL，粒径か ら砂洲を構成する材料および砂洲の南側で移流してい る有機泥には一次生産された有機物の付着が多いこ と, St.3に堆積する有機泥のILが最も大きいことから 洛東江が有機物の供給源の 1 つとなってることが推 定された。

（4）ジヌ島のSt.1〜St.2に至る断面には内陸部に凹部が あり, 雨水や大潮時に浸入した海水が保持されている. 内陸部の地下水位は降雨によって上昇し, 平常時は地 下水位が低下していることから活発な地下浸透がある ことが観測された．洛東江河口砂洲干潟では, 活発な 地下浸透によって砂干潟が形成されていることが推定 された。

\section{参 考 文 献}

西村尚哉, 駒井克昭, 今川昌孝, 日比野忠史 (2008) : 有機懸 濁物質の形成に関する基礎研究 - 有機物の付着特性一, 海岸工学論文集, 第 55 巻 (2), pp.1056-1060.

日比野忠史, 駒井克昭, 福岡捷二, 水野雅光（2008）：河口干 潟地盤内水環境に及ぼす浸透河川水の影響, 水工学論文 集, 第 52 巻, pp.1309-1314.

I.C. Lee, K.H. Kim, C.R. Ryu and Y.T. Kim (2005):Techniques for restoration/creation of ecological environmental zone in estuarine coastal area, Proceedings of the KOSMEE Autumn Annual Meeting, pp.32-37.

Seok-Yun Kim and Jeong-Su Ha (2001):Sedimentary facies and environmental changes of the Nakdong river estuary and adjacent coastal area, Journal of the Korean Fisheries Society, Vol. 34, No.3, pp.268-278. 